How Movements Move?

\title{
Evaluating the Role of Ideology and Leadership in Environmental Movement Dynamics in India with Special Reference to the Narmada Bachao Andolan
}

Padam Nepal

Abstract: Lawrence Cox (1999) has argued that the established perspectives on social movements operate with an inadequately narrow conception of the 'object' that is being studied and thus tends to 'reify' "movements" as usual activity against essentially static backgrounds, and in its place, he advocates a concept of social movement as the more or less developed articulation of situated rationalities. Following Cox, therefore, the present study perceives social movements as articulations of situated rationalities by perceiving them as a tactical, dialectical response to the harsh realities of the political system. This would help us capture the essential dynamic and transformative aspects of the movement. Any social movement, and for that matter, environmental movements are characterized by the presence of agencies and structural components, which, however, are not a priori and static. They are rather dynamic and get changed and transformed in the course of the movement. Precisely for this reason, the environmental movements can at best be comprehended by way of locating and analyzing the dynamism and transformations of the movements produced by the dialectical interaction of the various components and parameters of the movement over a span of time. Hence, the present paper aims to evaluate the dynamics and transformations of the environmental movements in India, taking the case of the Narmada Bachao Andolan, and, adopting a strategic relational approach within the agent-structure framework as its framework of analysis. For the present purpose, however, we have taken only two variables, namely, Ideology and Leadership and attempted the analysis of their contributions in producing movement dynamics.

Key words: Anti-dam movement, development, dynamism and transformations, environmental movements, hydropolitics, ideology, leadership, movements, social movements, strategic relational approach

W Tater in a contemporary society has undoubtedly become a site where contending perceptions meet. Recognizing the importance of the politics of water, Karl Wittfogel (1957) stated that every society is based on hydropolitics. The conflicts over water reflect the physical and symbolic character of water and can therefore focus on issues as diverse as particular physical infrastructure or nonstate specific ideology. The water is requisite to human life inevitably means that water is also fundamental to culture. Therefore, systems must be in place to distribute water in ways that reduce the possibility of conflict. Contemporary societies, however, have been experiencing a bourgeoning of water related conflicts throughout the world, especially with the rise and global spread of big dam building. Until 1960s1970 , the water discourse of the multilateral agencies can be described as the 'hydraulic mission' (Swyngedouw, 1998; Reisner, 1984), commensurate with the drive

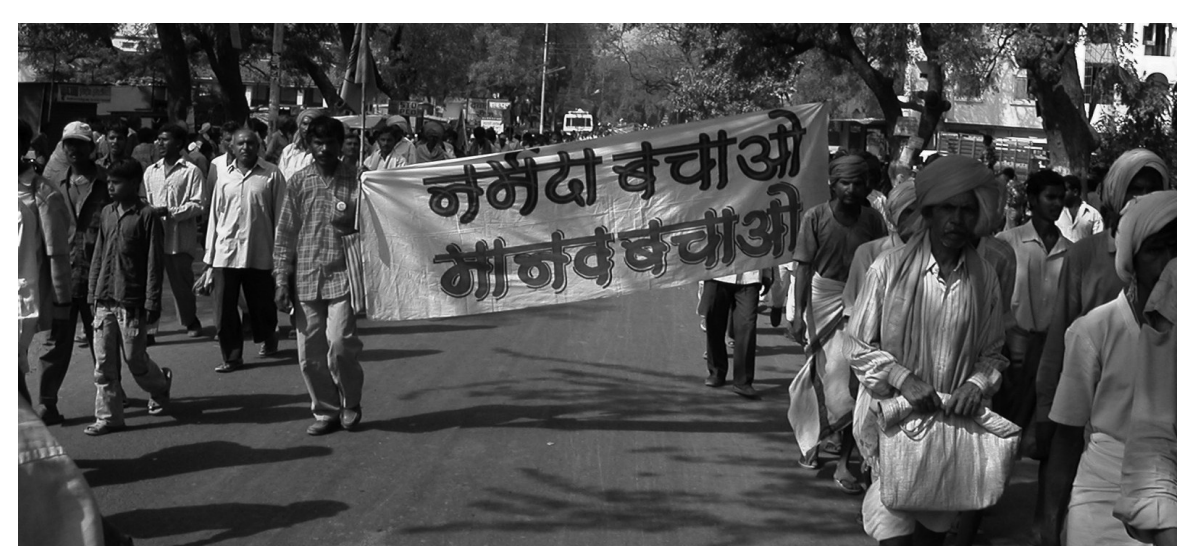

A rally on Narmada Bachao towards modernity in which settlements and ecosystems submerged during construction of dams were seen as necessary sacrifices for the greater common good. Since then, Wade (1997) describes the upsurge of environmental projects, assessments and strategies within the World Bank (which is the chief funding agency for such projects) as 'mission overload', responding to the pressure from beyond areas immediately affected by dams. Consequent to this, a negotiated 'complex multilateralism' emerges as the development agencies are influenced by, and form links with, social movements (O' Brien et al, 2000). This relationship with the non-state actors is new, but the depth and extent of the policy 'greening' is unclear as it is still emerging, and the movements and the multilateral agencies are diverse and internally differentiated. Thus, today the discourse on water and dams has become almost synonymous to the discourse on conflicts throughout the globe.
In India too, all major rivers are dammed or are in the process of being so. This has, however, not been able to deliver good to the local populace in the areas of the big dams, and therefore, the questions are now being raised about the viability of large dams that have often proved to be ecological disasters. Viewed in terms of their contribution to irrigation, the India Case Study Report of the World Commission on Dams (WCD) makes harsh judgement on the capacity of the large dams to deliver on promises of increased irrigation. In terms of 
Cost Benefits Ratio (CBR), the dams seem to have started off badly and gotten worse from there (see Nilsen, 2005 for details). We have little data, however, with which to review the performance of large dams in terms of their hydropower capacity. Nonetheless, it is now widely seen that the large dams have been criticized for the disasters related to them-social, economic, and environmental. The negative externalities produced by the construction of large dams have, therefore, resulted in the rise of conflicts, often culminating into large scale social movements in contemporary India, in the form of environmental movements, which constitute a bulk of the environmental movements in the country. The system of water harnessing through the construction of large dams and the resultant conflicts over the issue of distribution of water resources have, therefore, contributed to the multiplication of peoples' movements on the issue. The present study concerns with the Narmada Bachao Andolan.

\section{Background}

The Narmada Basin covers an area of approximately 94, 500 square kilometers between the Vindhya and the Satpura ranges in Central India. It is the site of the Narmada Valley Development Project (NVDP), an ambitious project that seeks to harness the river Narmada that flows through the three states of Madhya Pradesh, Maharastra and Gujarat, which envisages that 30 big dams, 135 medium dams, and 3000 small dams will be constructed on the Narmada river and its 41 tributaries.

The Narmada basin has such characteristic that has led the people to oppose the project envisaged by the state. This is because between gorges flanked by densely forested basaltic hills, the 1312 kilometers long Narmada Valley contains large alluvial plains in Madhya Pradesh. To the West, the Narmada River meanders through Gujarat widening into a 25-kilometer long estuary as it flows into the Gulf of Cambay. More than 22 million people live in the valley and several tribal groups, particularly Bhils and Gonds occupy the forested uplands. The project is estimated to affect over 0.25 Million of people. The Sardar Sarovar Project (SSP) and the Narmada Sagar Project (NSP) are the two largest dams to be constructed in the Narmada River, and the SSP alone will submerge 245 villages: 19 in Gujarat, 33 in Maharastra, and 193 in Madhya Pradesh. Thus these two projects have remained controversial owing to their largescale displacement and problems of humane rehabilitation. This has resulted in the emergence of a protest movement unique of its kind called the 'Narmada Bachao Andolan' (NBA).

The Narmada Bachao Andolan has drawn upon a multiplicity of discourses for protests such as displacement risks and resettlement provisions; environmental impact and sustainability issues; financial implications of the project; forceful evictions and violations of civil liberties; issues pertaining to river valley planning and management; implications of western growth model, and alternative development and appropriate technology, among many others. The movement uses various tools of protest such as Satyagraha (political action based on truth and non-violence as coined by Gandhi), Jal Samarpan (sacrificial drowning in the rivers), Rasta Roko (road blockade at strategic points), Gaon Bandhi (refusing the entry of government officials in to the villages), demonstrations and rallies, hunger strikes and blockade of projects.

The Narmada Bachao Andolan has successfully brought to the public domain the hitherto closed and protected discourse on mega development projects, thereby opening new vistas for environmental movements. The protest also has pointed out the necessity to address the shortcomings in institutional frameworks governing big developmental projects by laying bare the ecological implications of such mega development projects. As Routledge (2003) notes, the Narmada Bachao Andolan has been conducting its resistances across multiple scales. It has grounded its resistances against the project in the villages, and it has also taken the struggles to non-local terrains including the national and international levels. These resistances are articulated within a number of inter-related realms.

In the political realm, the Andolan has challenged the state centered and increasingly trans-corporate biased character of the political process, articulating critiques of neoliberal development ideology and the role of the state. In the environmental realm, it is involved in a struggle to protect local ecological resources like forests and rivers. In the economic realm, it articulates a conflict over access to productive natural resources like forests, land and water that are under threat of exploitation by the three riparian states and the transnational corporations.

And, finally, in the cultural front, it articulates to protect the identities and solidarities of the communities of the communities affected by the project which are grounded around issues of kinship, neighbourhood and the everyday social interactions. Hence, the movement involves interplay of various socio-political, economic and environmental variables at different levels from a local remote tribal hamlet to a sophisticated office of the transnational company at the international level. This complex interaction between the movement variables lend it the scope to move and transform, thereby affecting not only these variables but the entire relationship between the movement, the state and the public policy. This provides a challenging and a unique opportunity for a social scientist to comprehend its dynamic and transformative character and its consequent implications to public policy and the society. The movement, however, has awaited a comprehensive profile in terms of its dynamism and transformations.

The present study throws some light on the role of two variables, ideology and leadership, in producing movement dynamics.

\section{Mapping the Dynamics of the Narmada Movement}

In case of the Narmada Bachao Andolan, originated as a response to the Narmada Water Disputes Tribunal Award and is lead by charismatic leaders. Its activists are recruited from different sections of Indian society: the tribals of the affected area and the educated middle-class activists who 
have joined the movement from different urban centers in India in the course of the movement. It evolved, grew and still continues to grow, passing through different stages with its unique characteristics, shaped by various social relational factors, history, culture and the activists involved in the movement, nature of the target and the nature of the domestic and international environments. Thus, the movement is dynamic and it is constantly changing in its objectives, issues, strategies, and finally in its nature and content. We shall explore some key factors that have led to the movement of the movement and its consequent transformations at different levels in different stages of the movement.

\section{Ideology and Movement Dynamics}

Ideology is considered as one of the most important components of a protest movement. This is because the ideology is the legitimizing force of a movement and it is the ideological orientation of a movement that determines the objective of protest, and the strategy it needs to adopt to secure the goal so defined. The Narmada Bachao Andolan, like any other social movement has its own ideological premise based on which it develops its movement strategies and techniques. The NBA consists of individuals from diverse professions and ideologies-from right wing political party like the BJP to extreme left wing Maoists (Raina: 2003 ). Hence, one could very well say that socialist and Gandhian thought dominates the ideological orientations of the movement. Although the ideology has not been comprehensive, yet its basic tenets are premised on Gandhian idea of Satyagraha. The NBA has been driven very Gandhian belief that modern developmental projects supported by the state run roughshod over the needs of the rural poor, and that the only way to counter such a move of the state to safeguard the civil and economic rights of the people is through a non-violent mass resistance against the state. Hence it employs the Gandhian style Satyagraha as its strategies, and therefore, ideologically Gandhian. Hardiman (2003) has explained this Gandhian notion of Satyagraha as:

Satyagraha... is an amalgamation of two Gujarati words, Satya (truth) and Agraha (taking, seizing, holding), the implication being that one seizes hold of the truth... Gandhi understood that truth/satya was reached through a complex dialogue in which reasoned argument had often to be reinforced through emotional and political pressure. He knew that in many cases, reason by itself would not win an argument, for people tend to be swayed as much by emotion as by rational argument. This was where self inflicted suffering such as fasting could be important... Even then, additional political pressure was often needed entailing mass demonstrations, non-cooperation, tax refusal, hartals and the like.

In the context of Narmada Andolan, Satyagraha is seen as a deep 'symbolic- communicative' practice. The various strategies of Satyagraha like the Jal Samarpan, Gaon Bandi, and non-cooperation are symbolic in the sense that they represent and express the identity of the movement; they are communicative because they send messages to multiple recipients, who, in turn, assign to them 'multiple' meanings. Therefore, in a protest politics perspective, satyagraha constitutes an affirmation of the movement's resolve to attain its immediate objectives, say for instance, stopping the further construction to raise the dam heights. Satyagraha creates one common 'identity' for the movement participants by way of erasing the internal differences, and thereby creates a single unified force to reclaim 'symbolically' the 'eminent domain', where 'eminent domain' is understood as the legal principle by which the state claims its ownership over the stewardship of its resources.

Hence, Satyagraha is an integral and defining element of Gandhian ideology and its consequent strategy of dialogic resistance; simple application of the Gandhian style of Satyagraha implies a dialogic and discursive practice, something dynamic and non-static. It means that the ideology of the NBA which is largely Gandhian speaks for the fact that the movement is dynamic in nature. Given an ideology that is non-comprehensive and undefined, the movement has not had opportunities for manifesting ideological differences on ideological premises. This is not to suggest, however, that the lack of comprehensive and welldefined ideology has limited the scope of contradictions in the movement pertaining to ideological differences among the leaders. The nature and course of the movement and the movement strategies are also affected by the fact that there is an acute awareness in the movement regarding the need for a more inclusive, comprehensive and well defined ideology, and the Janashayog Trust set up from the funds received by the NBA from the Right Livelihood Award given to Medha Patkar has been organizing annual brainstorming meetings for the purpose. Hence, the ideological inadequacies of the movement also have provided the movement with motive force to move and transform with the necessities of the development of a newer ideology acceptable to all actors in the movement.

\section{Leadership and Movement Dynamics}

Leaders are central to social movements. Since leaders play a critical role in collective action, shaping movements in numerous ways like defining goals and advancing strategies, mobilizing followers, galvanizing organizations, and forging coalitions, they significantly influence responses to external repression. Moreover, the actions of the leaders, and their rhetoric and style affect the conflict outcomes in movements. Some studies define leaders as those who perform key tasks in a movement such as recruitment, mobilization of resources, and formation of movement organizations (McCarthy and Zald, 1977), or tactical innovation (McAdam, 1983), it also needs to be emphasized that movements make leaders as much as they are made by them. Some studies of the past also have focused on the leadership change that occurs during the course of a given movement. Blumer (1969) posited that leaders must shift roles acting as prophets during the first stages of protests, then as official representatives during the formalization of the movement, and finally as administrators 
as the movement institutionalizes. Rothman (1974) argued that different types of leaders may become prominent at various phases of protest, for instance, militant leaders dominating during the initial phases of protest while more accomodationist leaders coming to the forefront as the movement negotiates with its opponents. Although issues pertaining to the types and styles are not alien to the NBA, yet the NBA poses a question not so much of types and styles of leadership in the above sense per se, but a more complex issue of who constitute the leaders of the movement, the leadership conflicts arising between the adivasis and the urban activists who have taken the leadership positions in the movement, and finally, the question of representation of the interest of the affected community by the movement leadership. These issues surrounding the leadership have significantly determined the nature and course of the movement. The leadership of the movement is provided by a group of urban, educated, middle-class intellectuals from outside the Narmada Valley. The most prominent of the movement leaders are the charismatic Medha Patkar, followed by others like Chittaroopa Palit in the line of hierarchy, and more recently Arundhati Roy-a novelist turned activist, who is only second to Medha Patkar. The issues raised about the problem of leadership pertains to the personification of the movement in its leaders, absence of high ranking tribal leaders in the movement (Omvedt: 2004), and the question of representation of the tribal interest by the NBA leadership (Dwivedi, 1999; Baviskar, 1995).

The NBA leadership under Medha Patkar has been criticized for having created a situation of perceiving Medha as NBA and vice-versa. Thus the movement has been personified in its leaders. This has led to identifying the movement to a single leadership and therefore, has eclipsed the role played by others (adivasi) leadership in the initial phase of the mobilizations against the project. Gail Omvedt (2004) points out that the NBA leadership has failed to adequately acknowledge the contributions made specially by the tribal leaders like Wahuru Sonavane, who was once a leading young adivasi activists of Shramik Sangathana in Maharastra, and who had played a leading role in mobilizations in the initial phase of the movement since 1971-1972. Omvedt has pointed out that Medha Patkar has not given the credit of those tribal leaders who had organized on the issue before her. Omvedt built her criticisms on this failing of the NBA leadership from one poem entitled 'Stage' written by Wahuru on the non-assignment of any role to the tribal leaders like him. This short poem throws a deluge of light on the feeling of being neglected and being manipulated in the minds of the aspiring tribal leaders. This in fact reveals the existence of a rift, a conflict or rather an alienating gulf between the present urban activist leadership of the NBA and the aspiring tribal leaders who would better represent the tribal interests than by the activists from 'outside'. This leadership conflict that is emerging of late has posed a serious question of legitimate representation of tribal interests by the urban born activists. As such, therefore, one does not come across a confrontational personality clash among the leaders in case of the Narmada Bachao Andolan. The conflict here is of a different nature between the psychological experience of neglect in the aspiring tribal leadership and the iconic status of the urban educated middle-class activists who have been spearheading the movement. Moreover, there is also an emerging conflict on leadership questions between the young activists and the senior leaders of the movement. Most of the times, the young leaders feel neglected despite their hard struggles because of media coverage of the senior leaders. Young, aspiring leaders of the movement feel psychologically depressed as their names do not figure in the media coverage. This has been accepted even by the senior leaders like Medha Patkar herself. For instance, in an interview by Ashutosh Bhardwaj (n.d.), Medha Patkar says:

...once movement gathers strength they treat leader as celebrity. Media needs a face to project its stories... It at times hurdles growth of movement. There are so many activists involved in movement but projecting only one leader comes only at cost of other. I always tell my colleagues, who are younger to me, not to take note of such situation. Yet, young activist gets depressed at times and in fact run into argument with me over entire situation.

From the statement, it is obvious that the senior leaders have failed to project the young leaders as a 'face to project (its) stories' to the media, but rather keep the situation get going at the cost of the aspirations of the young leaders by just asking them 'not to take note of such situation.' Thus not only hurdles the movement but acts as a constraint on the way of generating a second and third generation line of dynamic leadership for the movement.

Another factor that provides the movement the energy to move and transform with the leadership is the role played by the knowledge class as the leaders of the movement, which too, is not without its associated tensions. One aspect of this tension is evident between the interest of those who directly experience environmental despoliation (the dam affected population in the present case) and the knowledge class who help to represent these interests in the political terrain. The potential tension between the two types of actors, is a major problem area as environmental struggles increasingly pervade a scientized domain, because such instances lead movements to value experts as more important resources than the locally affected people on whose behalf the struggle is being waged. In such situations, we can perceive at least two implications for the movement. First, the local links of the movement can get slackened, and second, it may lead to the alienation of the affected people from the movement itself (both these implications are evident in the present study, say for instance, the movement has been experiencing undulating developments in its support base, sometimes the local support from a part of the movement falling apart, and sometimes the movement moving outside the submergence area in the process of mobilizing support), thereby affecting the support base, strategy, demands and finally the nature of the movement itself. 


\section{Conclusions}

The NBA, which started as a struggle of the innocent, simple tribals has undergone a sea change in its course of over 20 years. Initially, when the movement began with its demand of the right to information about the costs and benefits of the dam and how the trauma of displacement would be compensated, the movement was a scattered one, with a series of sporadic protests by different organizations, dotting the three riparian states. This phases of the movement used lobbying and petitioning as its principal strategy. In 1988-1989, with all the organizations protesting against displacement by the Narmada Project and against the improper and inadequate resettlement and rehabilitation schemes coming together, the emerging collective was christened as the NBA. The nomenclature of the NBA as an emerging collective signified the transformation in the nature of the struggle from the scattered to a more coherent and a monolithic collective, with well defined objectives, demands and strategies guided by the ideology of Gandhian Satyagraha and led by urban, educated middle-class leadership, from outside the valley.

The turning point in the transformation of the nature of the NBA was the entry of the World Bank in to the scene and the campaigns of the movement to pressurize the Bank to withdraw from the project. Because, it was as a result of this that the movement transformed from a nationally recognized movement to a movement of international recognition and repute. This transformation was brought about by the changed nature of its objectives, issues and demands and the corresponding change in its strategy. The movement at this stage began to play the politics of alliance building with transnational groups, networking with various international NGOs and pressurizing the Bank to withdraw funding to the project. It stood with its agenda of total opposition to the dam and advocated a strong no-dam position. Although the Bank withdrew, the movement realized the limitations of the utopian no-dam position and softened its position to the review of the project. This was facilitated by the production of the counter-expertise on the project by the movement which could expose the hollowness of the government claims such as of rehabilitation, on hydrological data of the project, on cost-benefit matrix, and of land availability for resettlement, among many others.

In its next phase, the movement turned towards the villages again, keeping alive its spirits of alliance formations and networking at the national and international levels. Hamara Gaon Mein Hamara Raj became the theme of the movement. The movement attempted to garner support and reach deep to the villages, adopting the methods of village non-cooperation (Gaon Bandhi), preparing for monsoon satyagrahas by forming samarpit dals in the village. The impression thus created was that the people led the movement themselves; they were the leaders of their own village, their own movement. Its review politics and jury politics, however, continued even at this stage of the movement.

The movement also showed a shift in terms of its goals and objectives. Its next strategy was to advocate a reconstruction of the society, economy and polity by way of Nava Nirman in the valley. Nava Nirman was an experiment of the movement to develop an alternative system of participatory governance and sustainable development in the valley. Obviously therefore, Nava Nirman slogan should have reconstructed the ideology befitting all and rebuilt the leadership of the movement as well, which, however, did not happen.

One of the objectives of the movement behind the Nava Nirman strategy was to expose the futility and inefficacy of the governance system and development paradigm thrust upon the people by the state. The Nava Nirman centered on activities like opening up of the schools like the Jivan Saalas and developing micro-credit facilities for the local poor. NBA's jury politics failed with the Supreme Court verdict in 2000. The NBA protested against the decision leading to the arrest of many. Despite the blow meted on the NBA, it is still adamant and is striving for a more comprehensive and authoritative review of the dam by a new tribunal.

Although the verdict has sounded the death bell for the movement, yet the movement is thriving with an arduous toil, harping primarily on the issue of full and just rehabilitation of the already ousted people, and surviving as a part of the broader canvass of peoples' movement in India. Hence, in course of its evolution and development, the movement has undergone metamorphosis several times, with changes in its thematic orientations, changes in strategies, changes in support bases, and finally changes in the structure of the movement, from a local movement to a national one, and finally becoming a movement of global significance. These transformations are brought about by the interaction of movement variables, including the ideology of Gandhian idea of non-violent direct action, and the nature of the leadership.

Satyagraha being the strategy of dialogic and discursive resistance, it is dynamic and non-static. Therefore, the simple application of the ideology has led to the dynamism in the movement in the form of discursive and dialogic practices. Moreover, the ideology being non-comprehensive and undefined, the movement has not given opportunities for manifest ideological differences on ideological premises. This has also produced internal contradictions in the movement for want of a comprehensive ideological premise. The nature and course of the movement and the movement strategies are also affected by the fact that there is an acute awareness in the movement regarding the need for a more inclusive, comprehensive and well defined ideology.

With regard to the leadership, it was found that in case of the NBA, the leadership clash was noticed between the urban educated middle-class leadership of the movement coming from outside and the aspiring tribal leadership who have not been given their legitimate share in the movement leadership. This has resulted in the dwindling of the support base of the movement in places where the activists have chosen to accept the rehabilitation package of the government than to toe the leadership of the movement that undermines their role in the movement. Thus, the 
leadership and conflicts within the movement leadership has become an important factor unleashing dynamics in a movement and impacting on its nature and course.

Padam Nepal is Senior Lecturer and Head at the Department of Political Science, St Joseph's College, North Point, Darjeeling, India. He completed his MA, M. Phil and PhD from the University of North Bengal. He specializes in Environmental Politics and Advanced Political Theory. His research interests include Environmental movements, spatial, symbolic and material mediation of social movements, gender studies, micropolitics of development of marginal communities, folk and cultural aspects of politics, and politics of recognition.

Corresponding address: padamnepal@gmail.com

\section{References}

Baviskar, Amita, 1995, In the Belly of the River: Tribal Conflicts over Development in the Narmada Valley, New Delhi: Oxford University Press.

Bhardwaj, Ashutosh, n.d., 'Medha Patkar on completion of twenty years of Narmada Bachao Andolan,' an Interview with Medha Patkar.

Blumer, Herbert, 1969, 'Social Movements,' in Barry McLaughlin (ed.), Studies in Social Movements: A Social Psychological Perspective, New York: Free Press.

Cox, Lawrence, 1999, 'Power, politics and everyday life: The local rationalities of social movement milieu,' in P. Bagguley and J. Hearn (eds.), Transforming Politics: Power and Resistance, London: Macmillan.

Dwivedi, Ranjit, 1999, 'Displacement risks and resistance: Local perceptions and actions in the Sardar Sarovar,' Development and Change, 30(1):43-78.

Hardiman, David, 2003, Gandhi In His Time and Ours, Delhi: Permanent Black.

McAdam, Doug, 1983, 'Tactical innovation and the pace of insurgency,' American Sociological Review, 48(6):735-754.
McCarthy, John \& Mayer Zald, 1977, 'Resource mobilization and social movements: A partial theory,' The American Journal of Sociology, 82(6):1212-1241.

Nilsen, Alf Gunvald, 2005, The Valley and the Nation-The River and the Rage: A Study of Dispossession and Resistance in the Narmada Valley, India, unpublished thesis submitted towards the Degree of Dr. Polit., Department of Sociology, University of Bergen, Norway.

O'Brien, A, J. Scholte \& M. Williams, 2000, Contesting Global Governance: Multilateral Economic Institutions and Global Social Movements, Cambridge: Cambridge University Press

Omvedt, Gail, 2004, 'Struggle against dam or struggle for water? Environmental movements and the state,' in R. Vora \& S. Palshikar (eds.), Indian Democracy: Meanings and Practices, New Delhi: Sage.

Omvedt, Gail, n.d., 'Open letter to Arundhati Roy', URL: www. narmada .org.

Raina, Vinod, 2003, 'Revisiting Chipko Andolan,' Alternatives (December 6), URL: www.alternatives.ca/article1041.html.

Reisner, M., 1984, Cadillac Desert: The American West and Its Disappearing Water, New York: Penguin Books (revised edition, 1993).

Rothman, Jack, 1974, Planning and Organizing for Social Change, New York: Columbia University Press.

Routledge, Paul, 2003, "Voices of the dammed: Discoursive resistance amidst erasure in the Narmada Valley, India,' Political Geography, 22(3):243-270.

Swyngedouw, E., 1999, 'Modernity and hybridity: The production of nature: Water and modernization in Spain', Occasional Paper, Water Issues Study Group, School of Oriental and African Studies, January 25, (also published in 1999 as 'Modernity and hybridity: nature, regeneracionismo, and the production of the Spanish waterscape, 1890-1930 in the Annals of

Wade, Robert, 1997, 'Greening the bank: The struggle over the environment, 1970-1995', in D. Kapur, J. Lewis \& R. Webb (eds.), The World Bank: It's First Half-Century, Vol. 2, Washington DC: The Brookings Institution.

Wittfogel, K., 1957, Oriental Despotism, New Haven: Yale University Press. 